\title{
ANALISIS GIZI LIMBAH AMPAS KEDELAI SEBAGAI TEPUNG SUBTITUSI MIE UNTUK MENUNJANG SUMBER BELAJAR MATA KULIAH BIOKIMIA
}

\author{
Anggi Dwi Putri ${ }^{1}$, Fatimatuz Zuhro ${ }^{2}$, Ismul Mauludin Al Habib ${ }^{3}$ \\ IKIP PGRI Jember ${ }^{1,2,3}$ \\ adp.adp58@gmail.com ${ }^{1}$
}

\begin{abstract}
ABSTRAK
Tujuan penelitian untuk mengetahui analisis proksimat gizi produk mie okara yang berpotensi menambah nilai protein dan serat pangan pada mie dan apakah penelitian ini dapat dijadikan penunjang sumber belajar matakuliah biokimia. Tahap awal penelitian ini yaitu penepungan okara dilanjutkan dengan pembuatan mie basah okara dan menganalisis kandungan gizinya yang ditandai dengan tingginya kandungan serat dan protein dibandingkan mie terigu. Hasil penelitian menunjukkan komposisi nilai gizi mie basah dengan subtitusi tepung okara memiliki kadar protein $6,7 \%$, kadar abu 0,27\%, kadar air 66\%, kadar karbohidrat $26 \%$, kadar lemak $0,5 \%$, dan kadar serat $2,4 \%$. Kandungan serat mie okara mampu memenuhi kecukupan konsumsi serat yang dianjurkan United States Department of Agriculture (USDA) sebesar 25 - 30g per hari. Subtitusi tepung okara secara bermakna dapat meningkatkan nilai protein dan serat pangan pada mie basah. Data hasil penelitian analisis gizi mie okara menggunakan metode proksimat juga dapat digunakan sebagai penunjang sumber belajar mata kuliah biokimia.
\end{abstract}

Katakunci : uji proksimat, mie okara, limbah, sumber belajar.

\section{ABSTRACT}

Research this aim to know nutritional proximate analysis of okara noodle products that have the potential to add protein values and dietary fiber to noodles and whether this research can be used as a source of biochemistry learning resources. The initial stage of this research is the flouring okara followed by making wet noodle okara and analyze the nutritional content characterized by the high content of fiber and protein than wheat flour. The results showed that the nutritional value of wet noodles with okara flour substitution had $6.7 \%$ protein, ash $0.27 \%$, water $66 \%$, carbohydrate $26 \%$, fat $0.5 \%$, and fiber $2.4 \%$. The content of okara noodle fiber is able to meet the sufficiency of fiber consumption recommended by United States Department of Agriculture (USDA) amount 25 $30 \mathrm{~g}$ for a day. Substitution of okara flour can significantly increase the value of protein and dietary fiber in wet noodles. Data of research result from nutrient analysis of okara noodles using proksimat method can also be used as supporting source of biochemistry course study

Keywords : proximate test, okara noodles, waste, learning resources 


\section{PENDAHULUAN}

Indonesia merupakan negara yang memiliki masalah gizi ganda. Berdasarkan data Riskesdas (2013), prevalensi obesitas sebesar 19,7\% pada lakilaki pada tahun 2013 lebih tinggi dari tahun 2010 yaitu sebesar 7,8\%. Sedangkan prevalensi obesitas pada perempuan sebesar 32,9\% pada tahun 2013. Gizi lebih dapat menyebabkan terjadinya obesitas. Obesitas merupakan penyebab terjadinya penyakit generatif, seperti kardiovaskuler, diabetes mellitus, dan beberapa jenis kanker (Makaryani, 2013).

Dewasa ini, kurangnya konsumsi serat menjadi faktor yang dapat menyebabkan obesitas. Asupan serat makanan yang dikonsumsi masyarakat di perkotaan sekitar 9,9 g dan di pedesaan sekitar 10,7 g per orang (Depkes, 2008). Sedangkan jumlah kecukupan konsumsi serat yang dianjurkan United States Department of Agricultur (USDA) sebesar 25-30 g per hari (USDHH 2013). Menurut Kusharto (2006), untuk mengatasi masalah obesitas yaitu dengan pendekatan inovasi produk pangan tinggi serat. Di antara berbagai produk pangan. Mie merupakan makanan yang populer di Indonesia. Akhir - akhir ini konsumsi mie kian meningkat. Berdasarkan data yang dihimpun World Instant Noodles Association (WINA), total konsmusi mie instan di Indonesia mencapai 14,8 milyar bungkus pada 2016. Selain itu, pada 2017 diproyeksi akan kembali mengalami peningkatan hingga 16 milyar bungkus.

Asosiasi produsen tepung terigu (Aptindo) memprediksi tahun 2017 naiknya impor gandum yang mencapai 8,79 juta ton atau naik sekitar $6 \%$ dari tahun sebelumnya sebanyak 8,3 juta ton. Dengan demikian perlu alternatif untuk mengurangi impor tepung terigu. Saat ini hanya mie yang berbahan $100 \%$ tepung terigu yang banyak memiliki kandungan kalori, mie berprotein kecil dan tidak memiliki kandungan serat. Serat sangat dibutuhkan tubuh dalam rangka menjaga kesehatan pencernaan.

Kedelai memiliki kandungan protein cukup tinggi mencapai $45 \%$ dan 15\% serat pangan (Yustina \& Abadi, 2012). Ketersediaan ampas kedelai (Okara) pada saat ini sangat banyak seiring dengan menjamurnya home industri pengolahan kedelai. Hasil survei peneliti dari pabrik susu kedelai SKM (susu kedelai madu) yang terletak diperumahan mastrip Jember diperoleh bahwa dalam setiap hari produksi menghasilkan okara sebanyak $130 \mathrm{~kg}$. Berdasarkan percobaan peneliti mencoba $2 \mathrm{~kg}$ okara menghasilkan $400 \mathrm{~g}$ tepung okara, jadi dalam sebanyak $130 \mathrm{~kg}$ okara akan menghasilkan tepung okara sebanyak $26 \mathrm{~kg} / \mathrm{hari}$. Tepung okara memiliki kandungan serat makanan (dietary fiber) yang tinggi terutama kandungan protein kasar 28,36\%, lemak 5,52\%, serat kasar 7,6\% dan juga mengandung asam amino lisin dan metionin serta vitamin B (Hulopi, 2014). Penggunaan tepung okara sebagai bahan pengganti tepung terigu adalah sebagai salah satu alternatif untuk mengurangi impor gandum.

Sejauh ini, data penelitian mengenai analisis kandungan gizi limbah ampas kedelai sebagai tepung subtitusi dalam pembuatan mie masih belum ada 
publikasinya. Data penelitian yang ada terbatas pada publikasi penggunaan limbah okara sebagai tepung subtitusi dalam pembuatan kerupuk, seperti yang dilakukan Hulopi, (2014). Sedangkan penelitian tentang diversifikasi produk mie yang ada terbatas pada penggunaan subtitusi tepung ubi jalar ungu (Luthfia, 2012). Penelitian tentang analisis proksimat gizi produk mie okara yang berpotensi menambah nilai protein dan serat pangan pada mie belum pernah dilakukan. Penelitian ini sekaligus digunakan sebagai penunjang sumber belajar matakuliah biokimia.

Sumber belajar meliputi semua hal yang bisa digunakan untuk memberikan kemudahan bagi siswa dalam belajar dan menambah pengetahuannya. Dengan sumber belajar tersebut maka siswa mendapatkan fasilitas yang dapat memungkinkannya untuk belajar dengan baik. Biokimia merupakan mata kuliah di Perguruan Tinggi dan termasuk ke dalam salah satu jenis sumber belajar yang berupa Pesan yang menuangkan ide, fakta, arti dan data dengan kriteria 6 indikator sumber belajar diatas. Pada umumnya uji adanya zat karbohidrat, lemak dan protein dalam makanan dilakukan secara kualitatif. Pada penelitian ini digunakan uji proksimat. Analisis proksimat merupakan analisis kadar air, kadar abu, kadar protein, kadar lipida, dan kadar karbohidrat. Hasil analisis disajikan sebagai nilai kadar dalam satuan \% (persen). Menurut Lestari, et al., (2013) hasil analisis dapat memanfaatkannya dalam menyusun formula/resep makanan.

Hasil penelitian ini dapat digunakan sebagai sumber belajar mata kuliah biokimia. Pada umumnya penyampaian materi terkait uji kandungan makanan hanya berupa uji keberadaan kandungan lemak, karbohidrat dan protein tanpa mengetahui jumlah prosentase zat tersebut dalam makanan. Hasil dari uji proksimat dapat dimanfaatkan sebagai metode pengujian bahan makanan dengan melihat prosentase kandungannya. Oleh karena itu, penelitian ini dirancang untuk meningkatkan tahapan uji kandungan makanan sehingga dapat dimanfaatkan sebagai penunjang sumber belajar mata kuliah Biokimia.

\section{METODE PENELITIAN}

Penelitian ini menggambarkan suatu analisa kandungan gizi mie dari tepung okara menggunakan metode uji proksimat. Penelitian ini dilakukan di Laboratorium Fakultas Teknologi Pertanian Universitas Jember pada bulan Desember 2017. Mie dari tepung okara digunakan sebagai sampel. Teknik pengambilan sample menggunakan teknik puposif dengan cara mengambil 2 gram sampel dalam setiap uji kadar sesuai dengan ketentuan metode uji proksimat.

\section{Prosedur Penelitian}

\section{Persiapan Penelitian}

Menyiapkan ampas kedelai jenis kedelai kuning (Glycine max) susu kedelai yang masih segar sekitar 2-5 jam setelah proses penyaringan terakhir sari kedelai. 


\section{Persiapan Alat dan Bahan}

Alat-alat yang digunakan antara lain: timbangan digital, gelas ukur, sendok, baskom, spatula, pisau, nampan, panci, pencetak mie, oven, kompor, loyang aluminium, dan plastik. Bahan-bahan yang digunakan antara lain: tepung terigu, tepung tapioka, tepung okara, air, garam, dan telur.

Alat-alat untuk analisa antara lain: Cawan alumunium, desikator, oven, neraca analitik, thermometer, penjepit cawan, mortar, cawan porselen, tanur listrik Barnstead Thermoline 4800D, kertas saring, alat ekstraksi, soxhlet (kondensor dan pemanas listrik), labu lemak, kapas bebas lemak, pemanas Kjeldahl, ruang asam dengan aspirator, labu Kjeldahl, alat destilasi, buret, labu takar, pipet ukur, erlenmeyer, gelas beaker, pengaduk magnetic, batu didih, pipet tetes, gelas ukur, $\mathrm{pH}$ meter, tabung reaksi, tabung reaksi bertutup, alumunium foil, penangas air, pipet mikro, kertas whatman, penyaring vakum, corong, label, nampan, wadah kecil, plastik, dan texture profile analyzer TAXT-2, dan penangas. Bahan-bahan yang digunakan untuk proses analisa antara lain : Sample mie ampas kedelai, heksana, kalium sulfat $\left(\mathrm{K}_{2} \mathrm{SO}_{4}\right)$, air raksa $(\mathrm{HgO})$, asam sulfat pekat $\left(\mathrm{H}_{2} \mathrm{SO}_{4}\right)$, akuades, larutan $60 \% \mathrm{NaOH}-5 \% \quad \mathrm{Na}_{2} \mathrm{~S}_{2} \mathrm{O}_{3}-5 \mathrm{H}_{2} \mathrm{O}$ indikator (campuran dua bagian $0.2 \%$. merah metilen dalam etanol dan satu bagian $0.2 \%$ biru metilen dalam etanol), $\mathrm{HCl} 0.02 \mathrm{~N}$, buffer fosfat $0.08 \mathrm{M} \mathrm{pH}$ 6.0, termamyl (Sigma, St. Louis, US), $\mathrm{NaOH} 0.275 \mathrm{~N}$, protease, $\mathrm{HCl} 0.325 \mathrm{~N}$, amiloglukosidase (AMG), etanol 95\%, $\mathrm{Na}_{2} \mathrm{CO}_{3} 5 \%$, reagen Folin Ciocelteau 50\%, dan asam galat.

\section{Pembuatan Tepung Okara}

Uraian proses pembuatan tepung okara sebagai berikut:

1. Alat-alat dan bahan-bahan disiapkan

2. Bubur ampas kedelai ditimbang sebanyak $2 \mathrm{~kg}$

3. Bubur ampas susu kedelai diperas agar kandungan air dapat berkurang

4. Bubur ampas susu kedelai dikukus (15-20 menit)

5. Disangrai

6. Dikeringkan

7. Ampas kedelai yang sudah kering digiling dengan mesin penggiling

8. Tepung ampas susu kedelai diayak dengan menggunakan alat pengayak (80100 mesh)

9. Tepung ampas kedelai siap diolah (Hulopi, 2014)

\section{Pembuatan Mie Okara}

Prosedur percobaan pada pembuatan mie okara mengacu pada Luthfia (2012), dengan modifikasi sebagai berikut :

1. Pencampuran

2. Pengadukan dan Pengulian

3. Pembentukan Lembaran

4. Pembentukan Untaian 


\section{Perebusan \\ 6. Pendinginan \\ 7. Penirisan}

\section{Analisis Kandungan Gizi Mie Tepung Okara}

Analisis kandungan gizi mie okara adalah analisis proksimat yang meliputi kandungan kadar air, abu, karbohidrat, protein, lemak dan serat.

\section{Kadar Air Metode Oven (SNI 01-2891-1992)}

Cawan alumunium dikeringkan dalam oven dengan suhu $105^{\circ} \mathrm{C}$ selama 15 menit didinginkan, kemudian ditimbang (W2). Sejumlah sampel (W sekitar 1-2 gram) dimasukkan ke dalam cawan. Cawan beserta isi dikeringkan selama semalam, didinginkan di dalam desikator, dan ditimbang (W1). Perhitungan kadar air dilakukan dengan menggunakan rumus:

Kadar air $(\%)=\frac{\text { Berat air }(g)}{\text { Berat sampel }(g)} \times 100 \%$

\section{Kadar Abu (SNI 01-2891-1992)}

Cawan porselen kosong dikeringkan menggunakan oven bersuhu $105^{\circ} \mathrm{C}$ selama 15 menit kemudian didinginkan dalam desikator selama 15 menit dan ditimbang (W2). Sebanyak 2-3 gram sampel ditimbang (W) dan dimasukkan ke dalam cawan porselin. Selanjutnya sampel dipanaskan di atas hot 7 plate sampai tidak berasap lagi, kemudian dilakukan pengabuan di dalam tanur listrik pada suhu $400600^{\circ} \mathrm{C}$ selama 6 jam atau sampai terbentuk abu warna putih. Sampel kemudian didinginkan dalam desikator selanjutnya ditimbang (W1). Kadar abu dihitung dengan:

Kadar Abu $(\%)=\frac{\text { Berat Abu }(g)}{\text { Berat Sampel }(g)} \times 100 \%$

\section{Kadar Lemak Metode Soxhlet (SNI 01-2891-1992)}

Labu lemak yang akan digunakan dikeringkan ke dalam oven bersuhu $105^{\circ} \mathrm{C}$ selama 15 menit, didinginkan dalam desikator selama 15 menit dan ditimbang (W2). Sampel yang telah dihaluskan ditimbang (W sebanyak 1-2 gram), dibungkus kertas saring yang sudah dibentuk seperti selongsong. Kertas saring yang sudah berisi sampel dimasukkan dalam ekstraksi (soxhlet) yang berisi pelarut heksana dan dihubungkan dengan labu lemak. Ekstraksi lemak dilakukan selama 6 jam dan pelarut yang ada di dalam labu lemak disuling. Selanjutnya hasil ekstraksi dikeringkan dalam oven bersuhu $105^{\circ} \mathrm{C}$, kemudian dikeringkan di dalam desikator dan ditimbang (W1). Kadar lemak dihitung menggunakan :

Kadar lemak $(\%)=\frac{\text { Berat Lemak }(g)}{\text { Berat sampel }(g)} \times 100 \%$ 


\section{Kadar Protein Metode Kjeldahl (AOAC 960.52)}

Sejumlah kecil sampel sekitar 0.1 gram ditimbang dan diletakkan ke dalam labu Kjeldahl kemudian ditambahkan 1 gram $40 \mathrm{mg} \mathrm{HgO}, \mathrm{K}_{2} \mathrm{SO}_{4}$, dan $2 \mathrm{~mL}$ H2SO4. Selanjutnya ditambahkan 2-3 butir batu didih, kemudian larutan didihkan selam 1.5 jam sampai larutan menjadi jernih lalu larutan didinginkan dan dimasukkan ke dalam alat destilasi, kemudian larutan dibilas dengan akuades sehingga kristal terbentuk kembali dan ditambahkan $8 \mathrm{~mL}$ larutan $60 \% \mathrm{NaOH}-$ 5\% Na2S2O3. Erlenmeyer $250 \mathrm{~mL}$ yang berisi $5 \mathrm{~mL} \mathrm{H}_{3} \mathrm{BO}_{3}$ ditambahkan 3 tetes indikator (campuran 2 bagian metilen merah 0.2\% dalam etanol dan 1 bagian metilen biru $0.2 \%$ dalam etanol) dan diletakkan dibawah kondensor. Destilasi dilakukan sehingga diperoleh sekitar $15 \mathrm{~mL}$ destilat. Hasil dari destilasi tersebut kemudian diencerkan hingga sekitar $50 \mathrm{~mL}$ lalu dititrasi dengan $\mathrm{HCl} 0.02 \mathrm{~N}$ yang sudah distandardisasi hingga terjadi perubahan warna kondensat menjadi abu-abu. Penetapan blanko dilakukan dengan menggunakan metode yang sama seperti penetapan sampel. Kadar protein dihitung dengan menggunakan rumus:

$$
\begin{gathered}
\text { kadar } N(\% b b)=\left[\frac{(\mathrm{V} \text { HCI contoh }-\mathrm{V} \mathrm{HCI} \text { blanko }) \times \mathrm{NHCI} \times 14.007}{\mathrm{mg} \text { contoh }}\right] \times 100 \% \\
\text { kadar protein }(\% b b)=\% \mathrm{~N} \times \mathrm{Fk} \\
\text { kadar protein }(\% b k)=\left[\frac{\text { kadar protein }(b b)}{100-\text { kadar air }(b b)}\right] \times 100 \%
\end{gathered}
$$

Keterangan :

Fk : Faktor konversi (6.25)

\section{Kadar Karbohidrat by-difference}

Sampel kadar karbohidratnya dengan menggunakan rumus by difference sebagai berikut : Kadar Karbohidrat $(\%)=100 \%-(\%$ bk air $+\%$ bk protein $+\%$ bk lemak)

\section{Analisis Kadar Serat Metode Enzimatis (AOAC 589.29)}

Sampel sebanyak 1-2 gram diekstrak lemaknya terlebih dahulu menggunakan metode ekstraksi soxhlet dengan heksana selama 6 jam. Kemudian sampel diambil $0.5 \mathrm{~g}$ ke erlenmeyer dan ditambahkan $25 \mathrm{~mL}$ buffer fosfat $0.08 \mathrm{M}$ $\mathrm{pH}$ 6.0. Lalu ditambahkan $0.05 \mathrm{~mL}$ termamyl dan erlenmeyer ditutup dengan menggunakan alumunium foil. Larutan diinkubasi dalam penangas air bergoyang bersuhu $95^{\circ} \mathrm{C}$ selama 30 menit. Selanjutnya larutan didinginkan dan ditambahkan $5 \mathrm{~mL} \mathrm{NaOH} 0.275 \mathrm{~N}$ (sampai $\mathrm{pH}$ larutan mencapai 7.5). Kemudian larutan ditambahkan $0.05 \mathrm{~mL}$ protease, ditutup dengan alumunium foil, diinkubasi dalam penangas air bergoyang pada suhu $60^{\circ} \mathrm{C}$ selama 30 menit. Kemudian larutan didinginkan dan ditambahkan $5 \mathrm{~mL} \mathrm{HCl} 0.325 \mathrm{~N}$ (sampai Ph larutan mencapai 4.0-4.5). Larutan ditambahkan $0.15 \mathrm{~mL}$ amiloglukosidase (AMG), kemudian labu ditutup dengan alumunium foil, diinkubasi dalam penangas air bergoyang bersuhu 
$60^{\circ} \mathrm{C}$ selama 30 menit. Selanjutnya, larutan ditambahkan $140 \mathrm{~mL}$ etanol $95 \%$ bersuhu $60^{\circ} \mathrm{C}$ dan didiamkan selama 60 menit. Kemudian larutan disaring dengan kertas saring Whatman di penyaring vakum. Hasil saringan dicuci dengan 3 x 20 $\mathrm{mL}$ etanol 78\%, $2 \times 10 \mathrm{~mL}$ etanol 95\%, dan $2 \times 10 \mathrm{~mL}$ aseton. Setelah dicuci, kertas saring yang sudah berisi residu ditaruh dicawan alumunium kosong yang sudah diberi kode lalu dikeringkan pada suhu $105^{\circ} \mathrm{C}$ selama semalam (sampai bobot tetap). Hasil yang sudah kering didinginkan didalam desikator lalu ditimbang.

Penghitungan:

$\mathrm{W} 1$ = (Bobot hasil oven- bobot cawan alumunium - bobot kertas saring kering)

$\mathrm{W} 2=($ Bobot hasil tanur- bobot cawan porselen- bobot abu kertas saring $)$

$\mathrm{W} 3=(\%$ Kadar protein $\mathrm{x} \mathrm{W} 1)$

$\%$ Total serat pangan $=[(\mathrm{W} 1-\mathrm{W} 2-\mathrm{W} 3) / \mathrm{W}] \mathrm{X} 100 \%$

Keterangan:

$\mathrm{W}$ : bobot sampel (gram)

W1 : bobot residu hasil dari oven (gram)

W2 : bobot residu hasil dari tanur (gram)

W3 : Bobot residu hasil koreksi protein (gram)

\section{Teknik Pengumpulan Data}

Peneliti terlibat langsung pada setiap kegiatan dalam analisis kandungan gizi mie ampas kedelai yang terdiri dari tiga tahap. Tahap pertama adalah pembuatan tepung okara. Tahap kedua adalah pembuatan mie ampas kedelai dan tahap ketiga adalah uji proksimat pada produk mie tepung okara yang meliputi kandungan kadar air, abu, karbohidrat, protein, lemak dan serat.

\section{Analisis Data}

Data deskriptif yang diukur yaitu keberhasilan penelitian yang ditandai dengan adanya kandungan serat serta kandungan protein yang memenuhi standar mutu mie basah SNI 01-2897-2015. Parameter penelitian berupa kandungan gizi karbohidrat dan lemak mengacu pada standar mutu mie basah SNI 01-2897-1992. Sedangkan untuk parameter kandungan gizi protein, kadar abu dan kadar air mengacu pada standar mutu mie basah SNI 01-2897-2015

\section{HASIL PENELITIAN}

Mie basah dengan subtitusi tepung okara merupakan produk baru yang dikembangkan dalam rangka diversifikasi pangan. Prinsip pembuatan mie basah dengan subtitusi tepung okara pada dasarnya sama dengan pembuatan mie basah berbasis terigu. Bahan terigu penelitian ini adalah tepung terigu cakra kembar. Menurut Rahmawati (2016), tepung terigu berkualitas paling baik yang 
mengandung protein tinggi atau disebut dengan Hard flour, contohnya tepung cakra kembar yang memiliki kandungan protein sekitar 12\% - 13\%. Metode pembuataan mie mengacu pada Luthfia (2012), dengan modifikasi. Pertama proses pencampuran bahan kering seperti terigu, tepung tapioka, tepung okara, telur dan garam. Selanjutnya pengadukan dan pengulian sampai adonan benarbenar homogen. Adonan yang dihasilkan dalam penelitian ini kurang liat dan elastis, sesuai dengan pernyataan Yustina \& Abadi (2012), penggunaan tepung okara pada pembuatan produk makanan menghasilkan adonan yang kurang liat atau elastis sesuai dengan semakin besar jumlah penggunaan tepung okara. Hal ini karena tepung okara tidak memiliki protein gluten seperti halnya terigu yang membentuk adonan yang lengket dan elastis dengan penambahan air.

Tepung terigu mengandung protein yang tinggi, khususnya glutein yang berperan memberi tekstur kenyal pada makanan (Nofalina, 2013). Gluten merupakan komponen dalam tepung terigu yang dapat meningkatkan elastisitas maupun tekstur pada mie. Pada gluten terdapat protein yaitu glutenin dan gliadin. Protein tersebut merupakan komponen yang berpengaruh pada elastisitas mie. Oleh karena itu, semakin tinggi penambahan tepung okara dalam adonan, kandungan gluten didalamnya pun semakin sedikit sehingga akan menghasilkan mie yang bersifat rapuh dan mudah patah. Proses selanjutnya yaitu pembentukan lembaran dan pembentukan untaian mie dengan ukuran 1 - 2mm. Proses akhir yaitu perebusan mie dalam air mendidih $\left(100^{\circ} \mathrm{C}\right)$ selama 3 menit kemudian dilanjutkan dengan pendinginan dan penirisan yang bertujuan untuk mengurangi kadar air pada mie sehingga diperoleh mie dengan karakteristik berwarna putih.

\section{Analisis Proksimat Mie Okara}

Hasil analisis gizi mie basah dengan subtitusi tepung okara dapat dilihat pada Tabel 1 sebagai berikut :

Tabel 1. Komposisi Gizi Mie Okara (per 100 gr bahan)

\begin{tabular}{llll}
\hline No. & Zat Gizi & Jumlah $(\%)$ & Standar Mutu (SNI) Mie Basah \\
\hline 1. & Karbohidrat & $26 \%$ & $38-56 \%$ (SNI 01-2897-1992) \\
2. & Lemak & $0,5 \%$ & $1-2,5 \%$ (SNI 01-2897-1992) \\
3. & Protein & $6,73 \%$ & Min 6,0\% (SNI 01-2897-2015) \\
4. & Serat & $2,4 \%$ & - \\
5. & Kadar Air & $66,44 \%$ & Maks 65\% (SNI 01-2897-2015) \\
6. & Kadar Abu & $0,27 \%$ & Maks 0,05\% (SNI 01-2897-2015) \\
\hline
\end{tabular}

\section{Analisis Kadar Karbohidrat}

Karbohidrat merupakan senyawa yang terbentuk dari molekul karbon, hidrogen dan oksigen. Kadar karbohidrat yang diperoleh berdasarkan hasil penghitungan secara by difference sebesar 26,04\%. Jumlah tersebut menunjukkan bahwa kandungan karbohidrat dalam mie okara belum memenuhi standar mutu 
mie basah SNI 01-2987-1992 yang memiliki standar 38 - 56\% untuk kadar karbohidrat.

\section{Analisis Kadar Lemak}

Lemak adalah komponen makanan yang tidak larut dalam air. Kadar lemak pada mie okara menggunakan metode Soxhlet, sehingga diperoleh hasil penghitungan sebesar $0,51 \%$. Jumlah tersebut menunjukkan bahwa kandungan lemak dalam mie okara belum memenuhi standar mutu mie basah SNI 01-29871992 yang memiliki standar 1 - 2,5\% untuk kadar lemak. Kadar lemak pada mie okara dipengaruhi oleh kandungan lemak pada bahan utama pembuatan mie yaitu tepung okara dan tepung terigu yang memiliki kandungan lemak masing - masing sebesar $0,19 \%$ dan $0,02 \%$.

\section{Analisis Kadar Protein}

Protein merupakan sumber asam amino yang mengandung unsur karbon, hidrogen, oksigen dan nitrogen. Menurut Irina (2011), kebutuhan protein tergantung pada umur, ukuran tubuh, dan tingkat aktivitas. Kadar protein pada mie okara menggunakan metode Kjeldahl (AOAC 960.52), sehingga diperoleh hasil penghitungan sebesar 6,73\%. Jumlah tersebut menunjukkan bahwa kandungan protein dalam mie okara telah memenuhi standar mutu mie basah SNI 01-2987-2015 yang memiliki standar minimum 6\% untuk kadar protein.

\section{Analisis Kadar Serat}

Serat merupakan bagian dari makanan yang tidak mudah diserap oleh tubuh dan memiliki fungsi penting yang tidak dapat digantikan oleh zat lainnya (Farhatun, 2013). Kadar serat pada mie okara menggunakan metode enzimatis (AOAC 589.29), sehingga diperoleh hasil penghitungan sebesar 2,4\%. Angka ini cenderung meningkat dibandingkan penelitian terdahulu, diversifikasi produk mie basah dengan subtitusi tepung ubi jalar ungu memiliki kadar serat yaitu 1,40\% (Luthfia, 2012). Kadar serat mie basah dengan subtitusi tepung okara cenderung meningkat dengan semakin banyaknya jumlah subtitusi tepung okara. Hal ini disebabkan kandungan serat yang tinggi pada tepung okara yaitu sekitar 3,7\% /100 gram. Kandungan serat mie okara yang sebesar 2,4\% mampu memenuhi jumlah kecukupan serat yang dianjurkan United States Department of Agriculture (USDA) sebesar 25 - 30g per hari (USDHH 2013), sehingga mie okara dapat dijadikan sebagai pangan alternatif diet tinggi serat.

\section{Analisis Kadar Abu}

Abu merupakan residu anorganik setelah bahan dibakar dengan suhu tinggi (diabukan). Analisis kadar abu pada mie okara diperoleh hasil penghitungan sebesar 0,27\%. Jumlah tersebut menunjukkan bahwa kandungan abu dalam mie okara belum memenuhi standar mutu mie basah SNI 01-2987- 
2015 yang memiliki standar maksimum 0,05\% kadar abu. Kadar abu sangat dipengaruhi oleh jenis bahan yang dianalisis. Secara kuantitatif nilai kadar abu dalam mie okara yang dihasilkan berasal dari mineral - mineral dalam okara. Mineral dalam telur juga berperan dalam jumlah kadar abu mie. Menurut USDA Nutrient Database for Standard Reference mineral yang terdapat dalam telur adalah $\mathrm{Ca}, \mathrm{Fe}, \mathrm{Mg}, \mathrm{P}, \mathrm{Zn}, \mathrm{Mn}$ dan Se.

\section{Analisis Kadar Air}

Air merupakan komponen penting dalam bahan makanan karena air dapat mempengaruhi penampakan, tekstur, serta cita rasa makanan. Analisis kadar air pada mie okara diperoleh hasil penghitungan sebesar 66,45\%. Jumlah tersebut menunjukkan bahwa kandungan air dalam mie okara belum memenuhi standar mutu mie basah SNI 01-2987-2015 yang memiliki standar maksimal 65\% kadar air. Hal ini disebabkan mie basah yang dihasilkan merupakan mie basah matang yang sudah mengalami proses gelatinisasi sempurna dan sudah menyerap lebih banyak air pada saat proses perebusan. Kadar air perlu ditetapkan karena sangat berpengaruh terhadap daya simpan bahan. Makin tinggi kadar air suatu bahan, maka makin besar pula kemungkinan bahan tersebut rusak atau tidak tahan lama.

\section{PEMBAHASAN}

Analisis kandungan gizi limbah ampas kedelai sebagai tepung subtitusi dalam pembuatan mie menggunakan metode uji proksimat meliputi uji kandunngan kadar karbohidrat, kadar lemak, kadar protein, kadar serat, kadar air dan kadar abu. Karakteristik yang dimiliki setara dengan kriteria pemilihan sumber belajar yang mengacu pada Sudjana \& Rivai (2007), sebagai berikut :

\section{Ekonomis}

Pengerjaan analisis kandungan gizi limbah ampas kedelai sebagai tepung subtitusi dalam pembuatan mie menggunakan metode uji proksimat tergolong pengujian ekonomis dimana biaya pembuatan bahan dan uji proksimat berkisar antara 275.000,- sampai 300.000,- rupiah, dalam hal ini kita dapat memperoleh informasi kandungan gizi mie okara yang disajikan dalam satuan persen (\%) sehingga dapat menjamin bahwa mie okara bisa menjadi diversifikasi produk pangan untuk mengatasi masalah gizi lebih.

\section{Praktis}

Proses pengerjaan penelitian ini tergolong praktis karena prosedurnya menggunakan alat seperti Oven Labtech, Penangai Electromantel EME250, Timbangan Mattler Teledo, Tanur Carbolite dan Soxhlet merk Duran yang telah sesuai dengan metode analisis proksimat. 


\section{Sederhana}

Penelitian ini tergolong sederhana dalam pengerjaannya, karena proses penyiapan bahan tidak teralu rumit.

\section{Mudah Diperoleh}

Alat dan bahan yang digunakan dalam penelitian ini mudah diperoleh. Bahan yang digunakan berupa ampas kedelai (okara) yang diperolah dari home industri pengolahan susu kedelai yang mudah diperoleh dimasyarakat.

\section{Fleksibel}

Hasil penelitian dapat dimanfaatkan di bidang biokimia karena menggunakan metode uji proksimat untuk mengembangkan tahapan analisa uji kandungan makanan yang terdapat dalam sub bab karbohidrat, lemak dan protein. Penelitian ini juga dapat digunakan pada bidang ilmu gizi dan kesehatan sub bab karbohidrat, lemak dan protein karena dalam penelitian ini menghasilkan produk pangan berupa mie okara yang telah diketahui kandungan gizinya.

\section{Komponen Sesuai dengan Tujuan}

Pada bidang biokimia 1) mahasiswa mampu melakukan uji identifikasi karbohidrat, 2) mahasiswa mampu melakukan uji identifikasi lemak, 3) mahasiswa mampu melakukan uji identifikasi protein. Sedangkan pada bidang ilmu gizi dan kesehatan 1) mengkaji sumber karbohidrat, 2) mengkaji sumber lemak dan akibat kelebihan dan kekurangannya, 3) mengkaji sumber protein dan akibat kelebihan dan kekurangannya

Sesuai dengan hasil pengujian Kurikulum Perkuliahan dan SAP biokimia dalam penelitian ini menunjukkan hubungan yang setara bidang kajian penelitian terdapat pada kurikulum perkuliahan. Analisa uji kandungan gizi makanan tercantum dalam materi perkuliahan Biokimia. Maka dapat diterapkan sebagai sumber belajar dalam bentuk sumbangan informasi berupa analisis kandungan gizi limbah ampas kedelai sebagai tepung subtitusi dalam pembuatan mie menggunakan metode uji prosimat. Sesuai dengan pernyataan Lestari, dkk. (2013), dengan analisis proksimat akan dapat diketahui kandungan zat gizi mayor suatu bahan. Hasil penelitian ini diharapkan dapat bermanfaat dalam aplikasi praktikum maupun proses pembelajaran.

\section{SIMPULAN}

Hasil uji proksimat menunjukkan komposisi nilai gizi mie basah dengan subtitusi tepung okara memiliki kadar protein 6,7\%, kadar abu 0,27\%, kadar karbohidrat 26\%, kadar lemak 0,5\%, kadar air 66\% dan kadar serat 2,4\%. Tingginya kandungan serat pada mie okara mampu memenuhi jumlah kecukupan serat yang dianjurkan United States Department of Agriculture (USDA) sebesar 25 - 30 g per hari (USDHH 2013), sehingga mie okara dapat dijadikan sebagai 
pangan alternatif diet tinggi serat. Analisis kandungan gizi limbah ampas kedelai sebagai tepung subtitusi dalam pembuatan mie menggunakan metode uji proksimat dapat digunakan sebagai penunjang sumber belajar mata kuliah biokimia. Diperlukan penelitian lebih lanjut mengenai uji organoleptik meliputi rasa, warna, aroma, dan tekstur pada produk mie okara serta memperbaiki kandungan kadar karbohidrat, lemak dan kadar air agar sesuai dengan standar mutu mie basah SNI 01-2987-2015 dan SNI 01-2897-1992.

\section{DAFTAR PUSTAKA}

Depkes. (2008). Departemen Kesehatan Republik Indonesia. Kegemukan Akibat Kurang Serat. (ID): Depkes. Jakarta

Hulopi, F. (2014). Pemanfaatan Ampas Susu Kedelai sebagai Tepung Subtitusi dalam Pengolahan Kerupuk. Tugas Akhir. Universitas Negeri Gorontalo.

Kusharto, C. M. (2006). Serat Makanan dan Peranannya bagi Kesehatan; Jurnal Gizi dan Pangan, Institut Pertanian Bogor 1(2). 45 - 54.

Luthfia, A. (2012). Kadar Serat, Aktivitas Antioksidan, Amilosa dan Uji Kesukaan Mi Basah dengan Subtitusi Tepung Ubi Jalar Ungu (Ipomoea batatas var Ayamurasaki) Bagi Penderita Diabetes Melitus Tipe 2. Skripsi. Universitas Diponerogo. Semarang.

Lestari, L.A., Nisa, F.Z., \& Sudarmanto. (2013). Modul Tutorial Analisis Zat Gizi. Fakultas Kedokteran. Universitas Gadjah Mada. Yogyakarta.

Makaryani R Y. (2013). Hubungan konsumsi serat pangan dengan kejadian overweight pada remaja putri SMA Batik 1 Surakarta. Naskah Publikasi. Program Studi Gizi D3- Fakultas Ilmu Kesehatan. Surakarta (ID): Universitas Muhammadiyah.

Novalina, Y. (2013). Pengaruh Penambahan Tepung Terigu Terhadap Daya Terima, Kadar Karbohidrat dan Kadar Serat Kue Prol Bonggol Pisang. Skripsi. Fakultas Kesehatan Masyarakat. Universitas Jember.

Rahmawati, N. (2016). Peningkatan Nilai Gizi Mie Basah dengan Penambahan Tepung Kedelai dan Umbi Bit Merah (Beta vulgaris L. Var rubra L) Menggunakan Program Linier. Artikel. Universitas Pasundan Bandung.

Riskesdas. Riset Kesehatan Dasar. (2013). Laporan Nasional. Badan Penelitian dan Pengembangan Kesehatan. Departemen Kesehatan, Republik Indonesia.

Sudjana, N dan Rivai, A. (2009). Tehnologi Pengajaran. Sinar Baru. Bandung.

Yustina, I., \& Abadi, F. (2012). Potensi Tepung dari Ampas Industri Pengolahan Kedelai sebagai Bahan Pangan. Seminar Nasional Kedaulatan Pangan dan Energi. Universitas Trunojoyo Madura. 